\section{HYDROGENATION OF CITRONELLA OIL DERIVATIVES TO 3,7-DIMETHYL-1-OCTANOL AS POTENTIAL BIO-BASED ADDITIVES OVER MODIFIED NATURAL ZEOLITE CATALYSTS}

Silvester Tursiloadia*, Ralentri Pertiwia, Akbar Litiazb, Indri Badria Adilina ${ }^{a}$

aResearch Centre for Chemistry, Indonesian Institute of Sciences Kawasan PUSPIPTEK Serpong, Tangerang, 15314, Indonesia bFaculty of Sains and Technology, Islamic Syarif Hidayatullah State Islamic University, Jakarta, Indonesia
Article history

Received

10 March 2017

Received in revised form

18 July 2017

Accepted

6 September 2017

*Corresponding author silv001@lipi.go.id

\section{Graphical abstract}

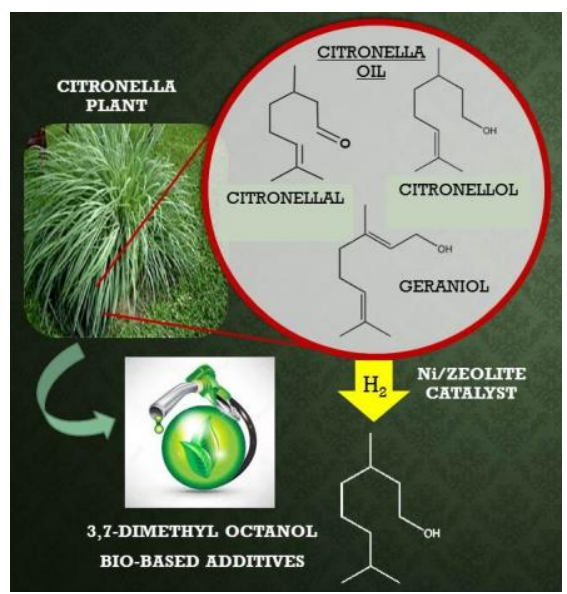

\begin{abstract}
An alternative way for saving energy and reduce emission in fuel consumption is using oxygenate compounds as fuel additives that can reduce carbon monoxide and soot that is created during the burning of the fuel. One derivatives of citronella oil fraction, 3,7-dimethyl-1-octanol, is a potential alcohol compound for fragrance and fuel additives producing efficiency energy and environmentally friendly. In this research, the conversion of citronella oil fraction (containing $>60 \%$ citronellal) into 3,7-dimethyl-1-octanol was investigated using Ni based natural zeolite-Bogor (ZAB) catalysts through hydrogenation process. The structure and properties of the Ni/ZAB catalysts have been investigated extensively using some of characterization techniques for solid materials i.e. XRF and TEM. Variations of weight catalysts and temperature reaction were conducted to determine the optimum conditions for this reaction. The products were analyzed using GC-MS instrumentation. The optimum conditions for the hydrogenation of citronella oil fractions using catalysts $\mathrm{Ni} / \mathrm{ZAB}$ $20 \mathrm{wt} \%-\mathrm{HT}$ were obtained at $300^{\circ} \mathrm{C}$ with $10 \%$ weight of catalysts produced $12 \%$ of the 3,7-dimethyl-1-octanol compound.
\end{abstract}

Keywords: Citronella oil derivatives, 3,7-dimethyl-1-octanol, natural zeolite, nicke zeolite, bio-based additives

(C) 2017 Penerbit UTM Press. All rights reserved

\subsection{INTRODUCTION}

As crude oil and petroleum products will have a certain quantity and it is reduced day by day, hence they are more expensive. There will be a great demand for fuel in the near future because of increases in number of automobiles and diesel engines. Due to these reasons, alternative fuel technology will become more common in the coming decades. Many studies have been reported in saving energy and reducing emission such as engine modification and the use of additives to increase fuel properties. Oxygenated additive is nothing more than fuel that have a chemical compound containing high oxygen content. It is used to help fuel burn more efficiently and cut down on some types of atmospheric pollution[1] Thus, many fuel additives have been studied to increase the fuel qualities and reduce exhaust emission such as FAME (Fatty Acid Methyl Ester) and MTBE (Methyl Tert-buthyl-ether). Previously, these compounds have been commercially used as oxygenated additives and raised the octane number but they have critically environmental and health concerns in many countries [2-4]. Some essential oils as bio-additive could improve engine performance by reducing fuel consumption as 
reported by Kadarohman et al. [5]. Terpene compounds contained in clove oil were largely and shorter ignition delay in engine fuelled by clove oil fuel blend and gave the highest total heat release with lower pressure at engine speed of $2500 \mathrm{rpm}$. Utilization of clove oil was also carried out by Sutrisno [6]. Performance of motorcycle was improved after adding clove oil and it can reduced fuel consumption by $30,07 \%$ at road test through the distance of $2,5 \mathrm{~km}$ and reach up to $30,30 \%$ at 1500 rpm for stationary test.

Citronella oil known as one of the major essential oils in Indonesia which has three main compounds i.e. citronellal, citronellol, and geraniol. 3,7-dimethyl-1octanol (DMO), often abbrivated as dihydrocitronellol, is one of alcohol groups that can be obtained from hydrogenation of citronella oil fraction [5]. This compound has molecular formula of $\mathrm{C}_{10} \mathrm{H}_{22} \mathrm{O}$ which is potential as oxygenated additive blended with diesel to improve combustion and reduce emissions of petrol engines. Furthermore, the boiling point of $\mathrm{DMO}$ is 213$218^{\circ} \mathrm{C}$ which is closer to that of diesel fuel $1180^{\circ} \mathrm{C}$ $360^{\circ} \mathrm{C}$ ) compared to the three aforementioned main compounds. Presence of a catalysts such as nickel can increase selectivity of 3,7-dimethyl-1-octanol in the hydrogenation process. However, nickel metal does not have a large surface area, hence not all of the active site can contact with the reactants. It needs to be distributed on a solid acid material such as zeolite. Natural zeolite is an abundant materials in Indonesia and provides as green materials for support catalysts in this reaction.

Extending our previous work [7-9], we will investigated $\mathrm{Ni}$ based zeolite catalysts to synthesize one of citronella oil derivatives compound, 3,7dimethyl-1-octanol, through hydrogenation process. The effect of temperature and amount of catalysts will be observed. Moreover, 3,7-dimethyl-1-octanol is a promising alcohol compound for bio-based additives reducing fuel consumption and emission.

\subsection{METHODOLOGY}

\subsection{Catalyst Preparation}

Natural zeolite was obtained from Bogor, Indonesia. Activation of natural zeolite and preparation of catalysts were performed as previous report [7]. In brief, pretreatment of natural zeolite (ZAB) was carried out using $\mathrm{HCl} 1 \mathrm{M}$ under constant stiring for $1 \mathrm{~h}$. The sample was filtrated and rinsed with distilled water until $\mathrm{pH}$ : 6-7. Zeolite was dried at $250^{\circ} \mathrm{C}$ for $3 \mathrm{~h}$ and ready to use as material support.

Nickel supported natural zeolite (Ni/ZAB) catalysts were obtained by impregnation method at $80^{\circ} \mathrm{C}$ with $10 \%$ and $20 \%(\mathrm{w} / \mathrm{W}) \mathrm{Ni}$ loading from $\mathrm{Ni}\left(\mathrm{NO}_{3}\right)_{2} .6 \mathrm{H}_{2} \mathrm{O}$ salt using ethanol as solvent. The solution was stirred until the solvent was slowly removed. After impregnation, the sample was dried at $120^{\circ} \mathrm{C}$ for $2 \mathrm{~h}$. Calcination process was conducted at $500^{\circ} \mathrm{C}$ for $2 \mathrm{~h}$ and then reduced with $\mathrm{H}_{2}$ flow at $300^{\circ} \mathrm{C}$ for $2 \mathrm{~h}$. As comparison, responsible to make a perfect solution between the bio-additive and pure fuel, led to rapid combustion other catalyst was directly reduced (without calcination) with $\mathrm{H}_{2}$ flow at $300^{\circ} \mathrm{C}$ for $2 \mathrm{~h}$.

\subsection{Catalyst Characterization}

The grain sizes of the samples were estimated from the images observed by TEM (FEI type Tecnai G2 20S-Twin). Elemental analysis of catalysts was measured by X-Ray Fluorosence (XRF). The other characterization of solid material such as surface area using BET method, crystal structure by X-ray diffraction (XRD), thermal analysis by TGA/DSC, and acidity properties were analyzed in previous report [7].

\subsection{Catalytic Test}

In this experiment, citronella oil was obtained from fractionational distillation process. Synthesis of 3,7dimethyl-1-octanol was carried out at $200^{\circ} \mathrm{C}$ in autoclave $200 \mathrm{~mL}$. Amount of catalyst was added between $5 \%(\mathrm{w} / \mathrm{W})$ and $10 \%(\mathrm{w} / \mathrm{w})$ from reactant. Citronella oil fraction was mixed with catalysts for $3 \mathrm{~h}$ with constant stirring at hydrogen pressure of $2 \mathrm{MPa}$. The products were analyzed by GC-Mass Spectrometry (Agilent 19091S, column HP-5MS $130 \mathrm{~m}$ x $250 \mu \mathrm{m}, 0.25 \mu \mathrm{m})$ ).

\subsection{RESULTS AND DISCUSSION}

\subsection{Properties of Catalyst}

Presence of ions such as $\mathrm{K}^{+}, \mathrm{Na}^{+}, \mathrm{Ca}^{2+}$ or $\mathrm{Mg}^{2+}$ in the zeolite surface can affect the activity of zeolite to be used in the reaction. Pretreatment, such as milling, heating and acidifying, is necessary to improve the character of natural zeolite. In this research, activation of natural zeolite by ion exchange method was performed using $\mathrm{HCl} 1 \mathrm{M}$ at room temperature for 1 hour replacing several ions such as $\mathrm{K}^{+}, \mathrm{Na}^{+}, \mathrm{Ca}^{2+}$ or $\mathrm{Mg}^{2+}$ with $\mathrm{H}^{+}$(Lewis acid site) which is required for the reaction. In addition, activation of zeolite will dissolve inorganic ions on the surface of natural zeolite.

According to the results in Table 1, it can be oberved that the concentration of $\mathrm{Ni}$ metal in the catalyst was detected as much as $2.5 \%$ for $\mathrm{Ni} / \mathrm{ZAB}$ $10 \mathrm{wt} \%$ catalyst and $4.9 \%$ for Ni/ZAB $20 \mathrm{wt} \%$ catalyst. Concentrations of $\mathrm{Al}$ and $\mathrm{Si}$ decreased following the increase of $\mathrm{Ni}$ metal content. This indicates that dealumination process is not only influenced by the activation process, but also with metal loading in the surface of zeolite. Dealumination process occurs when impregnation with $\mathrm{Ni}$ is carried out by througn heating. Additionally, ethanol used as the solvent can vaporize some impurities in the pores thereby affecting the crystal structure of the catalyst [10]. However, the ratio of $\mathrm{Si} / \mathrm{Al}$ increased with the addition of $\mathrm{Ni}$ metal. According to [11], dealumination process can increase the Si/Al ratio improving stability of zeolite catalyst in high temperatures. 
Table 1 Chemical composition of ZAB based catalysts

\begin{tabular}{lccc}
\hline Component & $\begin{array}{c}\text { ZAB } \\
\text { (\%) }\end{array}$ & $\begin{array}{c}\text { Ni/ZAB 10wt\% } \\
\text { (\%) }\end{array}$ & $\begin{array}{c}\text { Ni/ZAB 20wt\% } \\
\text { (\%) }\end{array}$ \\
\hline $\mathrm{Al}_{2} \mathrm{O}_{3}$ & 14,7 & 4,4 & 3,8 \\
$\mathrm{SiO}_{2}$ & 72,3 & 28,0 & 27,6 \\
$\mathrm{Ni}$ & - & 2,5 & 4,9 \\
$\mathrm{Al}$ & 7,8 & 2,3 & 2,0 \\
$\mathrm{Si}$ & 33,8 & 13,1 & 12,9 \\
$\mathrm{Si} /$ Al ratio & 4,3 & 5,6 & 6,4 \\
\hline
\end{tabular}

Figures 1 shows the TEM image of the Ni/ZAB-20wt\% catalyst. The Ni particles were well dispersed over the ZAB support. This was shown by the observation of black dots with small grains, around $20 \mathrm{~nm}$ in diameter. These particles should be exclusively localized on the outer surface of the zeolite crystallites.

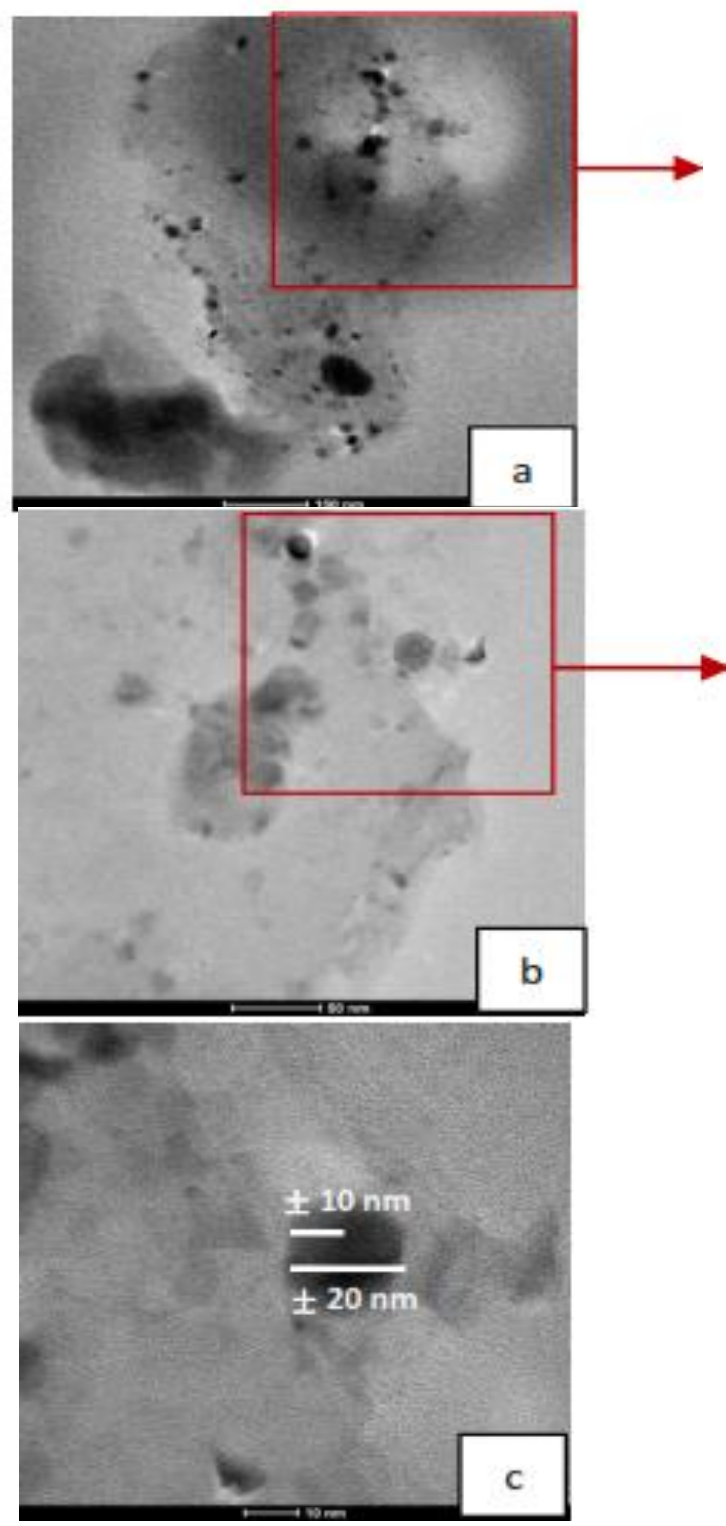

Figure 1 TEM images of Ni/ZAB-20wt\%-HT with magnification at (a) $100 \mathrm{~nm}$, (b) $50 \mathrm{~nm}$, (c) $10 \mathrm{~nm}$

\subsection{Catalytic Performance}

The hydrogenation process was carried out in an autoclave at reaction condition of $200^{\circ} \mathrm{C}$ for 3 hours with 20 bar of $\mathrm{H}_{2}$. In this reaction, the reactant (citronella oil fraction) was produced by fractionational distillation process of Cymbopogon nardus ( $P=80$ mbar, $R=20 / 10$ ) and contained up to $60 \%$ of citronellal and other components such as linalool (6.4\%) and citronellol (6\%). The specification of citronella oil fraction is given in Table 2 . and the analysis results using GCMS instrumentation is shown in Figure 2.

Citronellal has two active sides which are attached to the carbonyl $\mathrm{C}$ atom $(\mathrm{C}=\mathrm{O})$ and double bond $(\mathrm{C}=\mathrm{C})$ (Figure 3). The existence of carbonyl group in citronellal allow hydrogenation reaction to produce citronellol and 3,7-dimethyl-1-octanol (C-OH). High acidic catalyst can produce directly the hydrogenation product of citronellal i.e. citronellol and 3,7-dimethyl-1-octanol as results of their interaction with the $\pi$ bond in Ni sites [12, 13]. Hydrogen molecules will be adsorbed on the $\mathrm{Ni}$ active site. The relatively strong $\mathrm{H}-\mathrm{H}$ sigma bond is broken and replaced with two weak metal-H bonds. The $\pi$ bond of the alkene interacts with the $\mathrm{Ni}$ metal catalyst weakening the bond. A hydrogen atom is transferred from the catalyst surface to one of the carbons of the double bond. A second hydrogen atom is transferred from the catalyst surface forming the alkane. The alkane is released from the catalyst surface allowing the catalyst to accept additional hydrogen and alkene molecules. Finally, hydrogenation products are formed [14]. Conversion of citronella oil was performed by two different amount of the catalyst to reactants, i.e. $5 \%$ and $10 \%$. Table 3 shows the product analysis of hydrogenation process using various Ni/ZAB catalysts. The highest yield of 3,7-dimethyl-1-octanol was achieved using Ni/ZAB 20wt\%-HT catalyst (8\%).

From these results, it can be observed that the catalyst $\mathrm{Ni} / \mathrm{ZAB}-\mathrm{HT}$ with $20 \% \mathrm{Ni}$ loading and $10 \%$ amount of catalyst was able to produce $8 \% 3$,7dimethyl-1-octanol but also yielded $5 \%$ citronellol. On the other hand, a decreasing yield of both 3,7dimethyl-1-octanol and citronellol was seen accompanied by decreasing the amount of catalyst to $5 \%$. In the cases of Ni/ZAB 10wt\%-HT and Ni/ZAB 20wt\%-CLHT catalysts, lower conversion of citronella oil fraction were seen and only $1 \%$ of citronellol was formed. On the contrary, other citronella oil derivatives compounds were formed such as isopulegol and menthol. These products are results of the cyclization of citronellal in the presence of an acid catalyst continued with hydrogenation process of isopulegol as the intermediate product of menthol. In our previous study [7], the properties of these catalysts were investigated. The result concluded that the acidity decreased with increasing of $\mathrm{Ni}$ loading. According to our finding, crystalline structure of zeolite with large pores and high acidity, raised the ability of its properties, leading to the success of reactions to convert citronella oil fraction. The Ni/ZAB 20wt\%-HT 
catalyst had a larger surface area and higher ratio of $\mathrm{Si} / \mathrm{Al}$ compared to the other catalysts, which proved to increase the citronellal conversion to 3,7-dimethyl octanol. The higher surface area of catalyst will enhance the ability of catalyst to make contact with the reactants so the reaction become faster to yielded the products [10].

Table 2 Specification Component of Citronella Oil Fraction Used in Reaction by GC-MS

\begin{tabular}{|c|c|c|}
\hline Compounds & RT & $\%$ \\
\hline Limonene & 7.884 & 1.9 \\
\hline Melonal & 8.326 & 3.3 \\
\hline Linalool & 9.208 & 6.4 \\
\hline Citronellal & 10.830 & 66.0 \\
\hline Citronellol & 11.787 & 6.0 \\
\hline Citronellic acid & 12.880 & 2.6 \\
\hline Others & - & 13.8 \\
\hline
\end{tabular}

Abundance

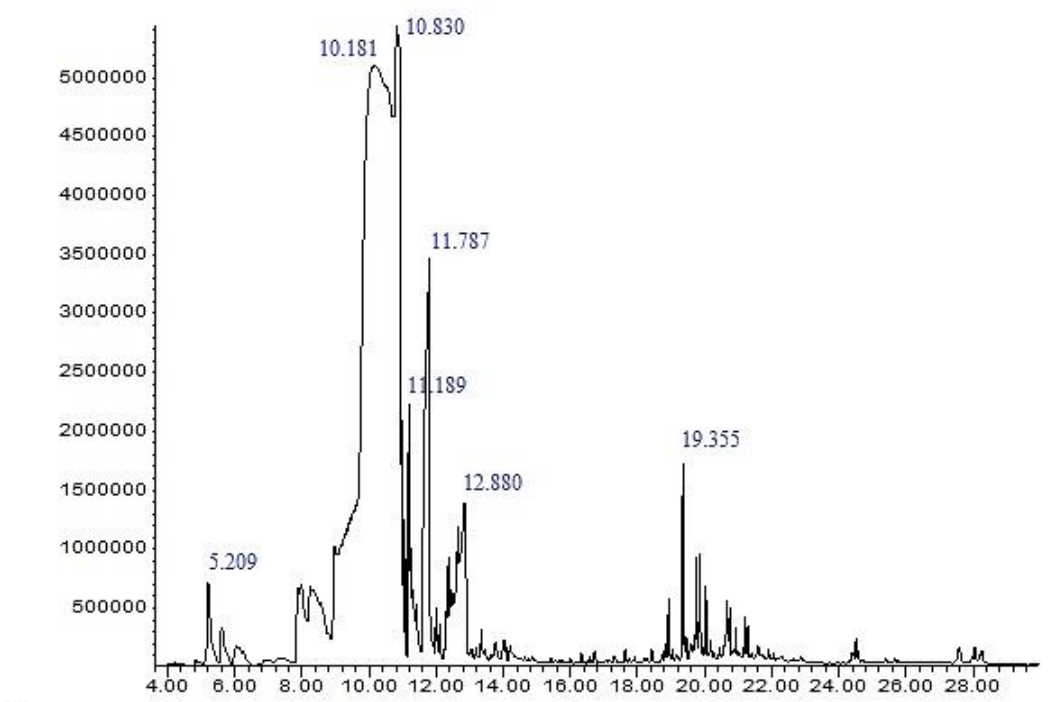

Time->

Figure 2 GC-MS Spectra of Citronella Oil Fraction

Table 3 Results of GCMS Analysis

\begin{tabular}{|c|c|c|c|c|c|c|}
\hline Catalysts & $\begin{array}{l}\text { Amount of } \\
\text { catalyst } \\
(\%)\end{array}$ & $\begin{array}{l}\text { Yield of } \\
\text { Citronellol } \\
(\%)\end{array}$ & $\begin{array}{c}\text { Yield of } \\
\text { 3,7-dimethyl- } \\
\text { 1-octanol (\%) }\end{array}$ & $\begin{array}{c}\text { Yield of } \\
\text { Isopulegol } \\
(\%)\end{array}$ & $\begin{array}{c}\text { Yield of } \\
\text { Menthols } \\
(\%)\end{array}$ & $\begin{array}{c}\text { Yield } \\
\text { Others } \\
(\%)\end{array}$ \\
\hline \multirow{2}{*}{ ZAB } & 5 & 0 & 0 & 11 & 0 & 88 \\
\hline & 10 & 0 & 0 & 0 & 0 & 100 \\
\hline \multirow{2}{*}{ Ni/ZAB 10wt\% CL-HT } & 5 & 0 & 0 & 36 & 2 & 94 \\
\hline & 10 & 0 & 0 & 31 & 0 & 69 \\
\hline \multirow{2}{*}{$\mathrm{Ni} / \mathrm{ZAB} \quad 10 \mathrm{wt} \% \mathrm{HT}$} & 5 & 1 & 0 & 33 & 9 & 57 \\
\hline & 10 & 0 & 0 & 13 & 14 & 77 \\
\hline \multirow{2}{*}{ Ni/ZAB 20wt\% CL-HT } & 5 & 1 & 0 & 58 & 0 & 42 \\
\hline & 10 & 1 & 1 & 18 & 18 & 62 \\
\hline \multirow{2}{*}{$\mathrm{Ni} / \mathrm{ZAB} 20 \mathrm{w}+\% \mathrm{HT}$} & 5 & 4 & 1 & 41 & 14 & 40 \\
\hline & 10 & 5 & 8 & 7 & 50 & 27 \\
\hline
\end{tabular}

Reaction conditions: 1 gr citronella oil, $200^{\circ} \mathrm{C}, 3$ hours, 20 Bar. ${ }^{*} \mathrm{CL}=$ calcination, HT = reduction 


\subsection{Effect of Temperature}

The effect of temperature was studied by using $\mathrm{Ni} / \mathrm{ZAB}$ $20 \mathrm{w}+\%-\mathrm{HT}$ at temperatures of $100^{\circ} \mathrm{C}, 200^{\circ} \mathrm{C}$, and $300^{\circ} \mathrm{C}$ for 3 hours at 20 bar $\mathrm{H}_{2}$. Analysis results of temperature variation are given in Table 4. At temperature of $100^{\circ} \mathrm{C}, 2 \%$ citronellol was formed over Ni/ZAB 20w+\%-HT catalyst, however, no yield of 3,7-dimethyl-1-octanol was obtained. In this temperature, the energy was not enough to break the $(\mathrm{C}=\mathrm{O})$ bonds and forming the aldehyde bonds (C-OH). The percentage of 3,7dimethyl-1-octanol increased when the temperature of $200^{\circ} \mathrm{C}-300^{\circ} \mathrm{C}$ were reached. The best performance of $\mathrm{Ni} / \mathrm{ZAB} 20 \mathrm{wt} \%-\mathrm{HT}$ catalyst was achieved at temperature of $300^{\circ} \mathrm{C}$ yielding $12 \%$ of 3,7 -dimethyloctanol with $12 \%$ selectivity. It may be ensured that not only $\mathrm{Ni}$ metal promoted the formation of 3,7dimethyl octanol, but also the reaction temperature applied. The temperature of this reaction can play a role in accelerating the hydrogenation process in which the reaction occurs at the termination double bond $(C=C)$ into a single bond $(C-C)$ and carbonyl $(\mathrm{C}=\mathrm{O})$ into a hydroxyl group $(\mathrm{C}-\mathrm{OH})$ [15]. The mechanism of hydrogenation process of citronellal to dimethyl octanol can be seen in Figure 3. It is threfore necessary to optimize the reaction condition and contents of citronella oil fraction in order to obtain a maximum yield of 3,7-dimethyl octanol, in which the condition should be based on a compromise between its contradicting effects on the time process.

Table 4 The result analysis of citronella oil fraction conversion by using GC-MS

\begin{tabular}{lccc}
\hline \multicolumn{1}{c}{ Catalysts } & \multicolumn{3}{c}{ Ni/ZAB 20w+\% HT } \\
\hline Temperature ( $\left.{ }^{\circ} \mathbf{C}\right)$ & 100 & 200 & 300 \\
Conversion (\%) & 52 & 97 & 100 \\
Yield of Citronellol (\%) & 2 & 5 & 5 \\
Yield of 3,7-dimethyl-1-octanol (\%) & 0 & 8 & 12 \\
Yield of Isopulegol (\%) & 0 & 7 & 4 \\
Yield of Menthol (\%) & 0 & 50 & 6 \\
Yield of Others (\%) & 98 & 27 & 73 \\
Selectivity of Dimetil Oktanol (\%) & 0 & 8 & 12 \\
\hline Reaction conditions: 1 gr citronella oil, 3 hours, 20 Bar, an 10\% of catalyst.
\end{tabular}

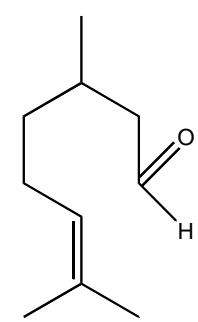

Citronelal

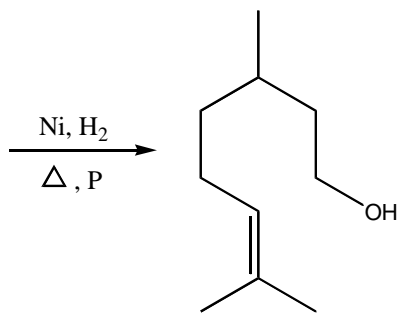

Citronelol

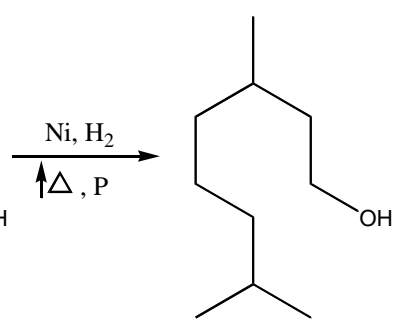

3,7-dimethyl-1-octanol

Figure 3 The plausible mechanism for conversion of citronellal to 3,7-dimethyl-1-octanol

\subsection{CONCLUSION}

Impregnation of nickel on activated natural zeolite with mordenite phase resulted a good catalytic performance for the hydrogenation of citronella oil fraction to 3,7-dimethyl-1-octanol and citronellol. The higher yield of $8 \%$ 3,7-dimethyl-1-octanol from citronella oil fraction was produced at $200^{\circ} \mathrm{C}$ reaction using Ni/ZAB 20w $+\%-H T$, meanwhile no formation was observed for Ni/ZAB 10wt\%-HT. The increase amount of $\mathrm{Ni}$ loading effected the catalysts properties such as rasio $\mathrm{Si} / \mathrm{Al}$, acidity, and surface area which then affected the hydrogenation process. The Ni/ZAB 20wt\%-HT catalyst had a larger surface area and higher ratio of Si/Al compared to the other catalysts, which proved to increase the citronellal conversion to 3,7-dimethyl octanol. The acidity and content of $\mathrm{Ni}$ metal in the surface of catalysts led to an increase in interaction with carbonyl on citronellal or citronellol structures internally. The optimum temperature for hidrogenation using Ni/ZAB 20wt\%-HT catalyst was achieved at $300^{\circ} \mathrm{C}$ and yielding of 12\% 3,7-dimethyl-1octanol. Furthermore, improvement in catalytic performance is certainly expected by optimizing the reactant content (citronella oil fraction) and reaction time. 3,7-dimethyl-1-octanol which is an oxygentated alcohol compound with boiling point close to that of diesel fuel have promising use for bio-based additives reducing fuel consumption and emission. 


\section{Acknowledgement}

The authors would like to express their gratitude to the Deputy of Engineering Science, Indonesia Institute of Sciences (IPT-LIPI) for financial support of this work.

\section{References}

[1] Sudarsanam, P., Mallesham, B., Prasad, A. N., Reddy, P. S., Benjaram and Reddy, M. 2013. Synthesis of Bio-additive Fuels from Acetalization of Glycerol with Benzaldehyde over Molybdenum Promoted Green Solid Acid Catalysts. Fuel Processing Technology. 06: 539-545.

[2] Yao, C., Zhang, Z., XU, Y. and Huang, Y. 2008. Experimental Investigation of Effects of Bio-Additives on Fuel Economy of the Gasoline Engine. Science in China Series E: Technological Sciences. 51 (8): 1177-1185.

[3] Chauhan, B. S., Singh, R. K., Cho, H. M., Lim, H. C. 2016. Practice of Diesel Fuel Blends Using Alternative Fuels: A Review. Renewable and Sustainable Energy Reviews. 59: 1358-1368

[4] Yang W. M., An, H., Chou, S. K., Vedharaji, S., Vallinagam, R., Balaji, M., Mohammad, F. E. A., Chua, K. J. E. 2013. Emulsion Fuel With Novel Nano-Organic Additives for Diesel Engine Application. Fuel. 104: 726-731.

[5] Kadarohman, A., Hernani, Rohman, I., Kusrini, R., Astuti, R. M. 2012. Combustion Characteristics of Diesel Fuel on One Cylinder Diesel Engine Using Clove Oil, Eugenol, and Eugenyl Acetate as Fuel Bio-Additives. Fuel. 98: 73-79.

[6] Sutrisno. 2015. Effect of Using Cloves Oil as Bio-Additive Fuels on the Performance of A4-Strokes Petrol Motorcycle, Lampung: Fakultas Teknik, Universitas Lampung.
[7] Tursiloadi, S., Litiaz, A. A., Pertiwi, R., Adilina, I. B., Sembiring, K. C. 2015. Development of Green-Nickel Based Catalysts for Citronella Oil Conversion to Isopulegol. Procedia Chemistry.16: 563-569.

[8] Adilina, I. B., Agustian, E. 2014. Green Synthesis of Isopulegol from Citronellal Catalysed by Zeolite Based Solid Acid Catalyst. Jurnal Chimica Et Natura Acta. 2(1): 58-60.

[9] Pertiwi, R., Tursiloadi, S., Adilina, I. B., Sembiring, K., Oaki, Y. 2016. Nickel Supported Natural Zeolite as a Bifunctional Catalysts for Conversion of Citronella Oil Crude to Menthol. Indonesian Journal of Applied Chemistry. 18(2): 132-137.

[10] Budiyanto, R. 2012. Aktivitas dan Selektivitas Katalis $\mathrm{Ni} /$ H5NZA terhadap Hidrorengkah Metil Oleat menjadi Senyawa Hidrokarbon Fraksi Pendek, Jember: Universitas Jember.

[11] Mahardiani, L., Trisunaryanti, W. and Triyono. 2010. Preparation and Characterization of Natural Zeolite Catalyst for Hydrocracking of Process. The 2th International Conference on Chemical Sciences (ICCS-2010). Yogyakarta, Indonesia. 14-16 October 2010.

[12] Chuah, G. K., Liu, S., Jaenicke, S. and Harrison, L. 2001. Cyclisation of Citronellal to Isopulegol Catalyzed by Hydrous Zirconia and Other Solid Acids. Journal of Catalysis. 200: 352-359.

[13] Milone, C., Gangemi, C., Ingoglia, R., Neri, G., Galvagno, S. 1999. Role of the Support in the Hydrogenation of Citronellal on Ruthenium Catalysts. Applied Catalysis A: General. 184: 89-94.

[14] Adilina, I. B., Pertiwi, R. and Sulaswatty, A. 2014. Conversion of Citronella Oil and Its Derivatives to Menthol over Bifunctional Nickel Zeolite Catalysts. Biopropal Industri. 6(1): $1-6$.

[15] Fessenden, R. and Fessenden, J. 1986. Kimia Organik Jilid 2. 3 Edisi Ke-2. Jakarta: Erlangga. 